\title{
SENYVO AMŽIAUS MOTERŲ FIZINIO AKTYVUMO, GYVENIMO KOKYBËS IR SUBJEKTYVIOS GEROVE்S YPATUMAI BEI SĄSAJOS
}

\author{
Andrejus Černovas, Vidmantas Alekna, Marija Tamulaitienė, Greta Katavičiūtė, \\ Rimantas Stukas \\ Vilniaus universiteto Medicinos fakultetas
}

Raktažodžiai: senyvas amžius, moterys, fizinis aktyvumas, gyvenimo kokybė, subjektyvi gerovè.

\begin{abstract}
Santrauka
Tyrimo tikslas - ištirti 60 metų ir vyresnio amžiaus moterų fizinio aktyvumo, gyvenimo kokybès ir subjektyvios gerovès ypatumus bei tarpusavio sąsajas. Tyrimo medžiaga ir metodai. Vienmomentis skerspjūvio tipo tyrimas atliktas $2017 \mathrm{~m}$. rugsèjo-gruodžio mèn. Tiriamujų apklausa buvo vykdoma tiesiogiai, naudojant bendraji ir specialiuosius klausimynus. Bendrajame klausimyne buvo registruojami sociodemografiniai duomenys, ūgis, kūno masé, apskaičiuotas kūno masès indeksas. Specialieji klausimynai buvo skirti įvertinti senyvo amžiaus moterų fizini aktyvumą (angl. Physical Activity Scale for Elderly, $P A S E$ ), gyvenimo kokybę (angl. Control, Autonomy, Self-realization, Pleasure, CASP-19) ir subjektyvią gerovę (angl. Positive and Negative Affect Schedule, PANAS; angl. Satisfaction With Life Scale, SWLS). Statistinè duomenų analize atlikta naudojant SPSS 18.0 for Windows programų paketą.

Rezultatai. Tyrime dalyvavo 103 moterys, kurių vidu-

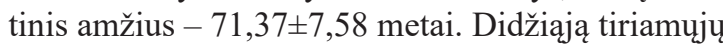
dalị sudare miesto gyventojos, turinčios aukštaji išsilavinimą, daugiau nei pusè jų gyveno vienos. PASE, CASP-19 (kontrolès, autonomijos sritys), PANAS-PA ir PANAS-NA klausimynų vidutiniai ịverčiai statistiškai reikšmingai skyrèsi 60-69 m., 70-79 m. ir $80 \mathrm{~m}$. ir vyresnio amžiaus grupèse. CASP-19 klausimyno kontrolès srities vidutiniai ịverčiai buvo mažiausi našlių moterų grupejje, aukščiausi - neištekejjusių arba išsiskyrusių moterų grupejje. PASE, CASP-19 klausimyno autonomijos srities vidutiniai ịverčiai didesni aukštajị išsilavinimą turinčių moterų grupejje, taip pat jos jaučia daugiau teigiamų (PANAS-PA) ir mažiau neigiamų (PANAS-NA) emocijų, nei moterys su ma-
\end{abstract}

žesniu išsilavinimu. Fizinis aktyvumas vidutiniškai stipriai koreliavo su teigiamo emocingumo vidutiniais iverčiais. Nustatyti vidutinio stiprumo koreliaciniai ryšiai tarp gyvenimo kokybės ir subjektyvią gerovę vertinančių klausimynų vidutinių ịverčių.

Išvados. 1. Mūsų tyrimo rezultatai parodè, kad $80 \mathrm{~m}$. ir vyresnio amžiaus moterų fizinis aktyvumas mažesnis, gyvenimo kokybė blogesnè, jos patyrè mažiau teigiamų ir daugiau neigiamų emocijų, negu jaunesnès (60-79 m.) senyvo amžiaus moterys. Mieste gyvenančių, aukštajị išsilavinimą turinčių moterų fizinis aktyvumas buvo didesnis, jos patyrè daugiau teigiamy ir mažiau neigiamų emocijų negu gyvenančios kaime. Mieste gyvenančių moterų gyvenimo kokybẻ buvo geresnè nei gyvenančių kaime. 2. Senyvo amžiaus moterų fizinis aktyvumas stipriai susijęs su teigiamu emocingumu, gyvenimo kokybè - su teigiamu emocingumu ir pasitenkinimu gyvenimu. Pasitenkinimas gyvenimu buvo susijęs su savęs realizavimo sritimi.

\section{Ivadas}

Gyventojų senejjimas - viena aktualiausių šių dienų visuomenès sveikatos problemų, veikianti šalies ekonomiką, socialinę politiką ir sveikatos apsaugos sistemą. Lietuvos statistikos departamento duomenimis, $2018 \mathrm{~m}$. pradžioje Lietuvoje gyveno 2808,9 tūkst. gyventojų, iš jų 730,2 tūkst. (arba 26 proc.) buvo 60 metų ir vyresni [1]. Ilgesnè gyvenimo trukmè yra teigiamas reiškinys, tačiau ilgiau gyvendami žmonès daugiau susiduria su socialinių vaidmenų pasikeitimu, artimujų netektimis, finansinėmis problemomis, vienatve; su amžiumi taip pat dideja rizika susirgti lètinèmis ligomis, daugeja ir psichikos sveikatos sutrikimų, tokių kaip depresija, nerimas, demencija [2]. Pasaulio sveikatos organizacija (PSO) sveikatą apibrèžia ne tik kaip ligos ar negalios nebuvimą, o kaip socialinę, fizinę, psichinę ir dvasinę žmogaus gerovę. Net 50 proc. sveikatos lemia žmogaus elgsena arba gyvenimo būdas: fizinis aktyvumas, mityba, 
žalingi ịpročiai, darbo-poilsio režimas, patiriamas stresas [3]. A. Juozulyno ir bendraautoriu atlikto tyrimo, kuriame dalyvavo 55-89 m. amžiaus žmonės, rezultatai parodè, kad tik 20,1 proc. tiriamujų fizinis aktyvumas buvo pakankamas; pastarujų didžioji dalis ( 82,8 proc.) gyveno mieste. Dauguma (75,8 proc.) tiriamųų teigé, kad sveikatą galima pagerinti vartojant vaistus ir ilsintis [4]. R. Valintelienès ir bendraautoriu atlikto Lietuvos reprezentacinio 15-74 m. amžiaus asmenų tyrimo rezultatai liudija, kad 61-74 m. amžiaus grupejje daugiau nei pusė (67,3 proc.) tiriamųjų neužsièmé jokia fizine veikla, beveik trečdalis tiriamujų (30,2 proc.) atitiko vidutinio ir tik 8,4 proc. - didelio intensyvumo fizinès veiklos kriterijus. Autoriai nustate, kad fizinis aktyvumas yra nepakankamas moterų ir asmenų su aukštuoju išsilavinimu grupėse [5]. Mokslinèje literatūroje pateikiama ịrodymų, kad fizinis aktyvumas yra svarbus visose amžiaus tarpsniuose, tačiau ypatingai - senyvame amžiuje, nes mažina sergamumą ir mirtingumą nuo daugelio ligų, gerina senyvo amžiaus asmenų gyvenimo kokybę ir subjektyvią gerovę [6-7].

Gyvenimo kokybès sąvoka yra daugialypè, ją B. K. Haas apibūdina kaip subjektyvios gerovès suvokimą, kuris apima fizinę, psichologinę, socialinę ir dvasinę dimensijas [8]. Vienas iš vedančiụjų mokslininkų, sukūręs subjektyvios gerovės koncepciją, E. Diener, teigia, kad ją sudaro du komponentai: emocinis ir kognityvinis. Emocinis komponentas apima emocines reakcijas (teigiamas ir neigiamas) i gyvenimo įvykius, o kognityvinis - bendrą asmens pasitenkinimą gyvenimu, arba atskiromis jo sritimis: laisvalaikiu, asmeniniais santykiais, darbu ir kt., visa tai yra subjektyvios gerovès konstrukto struktūros pagrindas [9]. Lietuvoje subjektyvi gerovè dažniausiai tirta sociologijos ir psichologijos disciplinose. G. Šilinskas ir R. Žukauskienè tyrẻ Lietuvos miestuose dirbančių vyrų subjektyvią gerovę ir nustate statistiškai reikšmingų skirtumų priklausomybę nuo išsilavinimo ir vidutinių pajamų. Autorių teigimu, tokie subjektyvios gerovès komponentai kaip teigiamas ir neigiamas emocingumas, pasitenkinimas gyvenimu yra susiję su specifinemis gyvenimo sritimis [10].

R. Žukauskienès ir bendraautorių atlikto tyrimo, kuriame dalyvavo Vilniuje dirbančios moterys, rezultatai parode, kad subjektyvi gerovė susijusi su socialiniais ir demografiniais veiksniais. Nustatyta, kad stipriausi tyrimo dalyvių subjektyvios gerovès prognostiniai veiksniai - išsilavinimas ir pajamos. Tyrimo duomenimis, ištekejjusios arba gyvenančios su partneriu tyrimo dalyvès buvo labiau patenkintos gyvenimu, negu neištekejjusios. Šeiminè padètis buvo stipresnis subjektyvios geroves prognostinis rodiklis, kuomet kartu vertintas su kitais veiksniais. Aukštasis išsilavinimas ir didelès pajamos nebuvo subjektyvios gerovès prognostiniai rodikliai, kuomet buvo vertinti kartu su asmenybiniais veiksniais [11]. D. Daukantaite ir R. Žukauskienẻ lygino Lietuvoje ir Šve- dijoje dirbančių moterų subjektyvią gerovę ir nustatè, kad Švedijos moterų subjektyvios gerovès komponentų (teigiamas ir neigiamas emocingumas, pasitenkinimas gyvenimu) rodikliai yra aukštesni nei to paties amžiaus Lietuvoje dirbančių moterų, išskyrus išorini pasitenkinimą gyvenimu [12]. G. Vaznonienè tyrè Lietuvos $60 \mathrm{~m}$. ir vyresnio amžiaus asmenų subjektyvią gyvenimo kokybę (subjektyvi asmens savivoka apie jo gyvenimo kokybę arba apskritai gyvenimą remiasi patirtimi ir išgyvenimais skirtingose gyvenimo srityse: ekonominèje, socialinėje, kultūrinejje, politinejje ir kt.). Autoré nustate statistiškai reikšmingus subjektyvios gyvenimo kokybės skirtumus tarp 60-69 m., 70-79 m. ir $80 \mathrm{~m}$. ir vyresnio amžiaus žmonių grupių. Didžioji dalis tyrimo dalyvių savo subjektyvią gyvenimo kokybę, pasitenkinimą dabartiniu gyvenimu vertino vidutiniškai. Autorė nustate, kad moterims ypač aktuali yra šeiminè situacija [13]. J. Miežytė-Tijūšienė ir L. Bulotaite tyrẻ Vilniaus miesto pensinio amžiaus žmonių suvokiamą gerovę ir subjektyvios gerovés komponentą - pasitenkinimą gyvenimu, ir rado socialinio aktyvumo, suvokiamos gerovès, pasitenkinimo gyvenimu teigiamas tarpusavio sąsajas [14]. T. Pawlowski su bendraautoriais, išanalizavę 19-os Europos Sajungos valstybių senyvo amžiaus gyventojų duomenis, nustate teigiamas sąsajas tarp fizinio aktyvumo ir subjektyvios gerovès: senyvame amžiuje fizinio aktyvumo poveikis subjektyviai gerovei yra didžiausias [15].

Šio tyrimo tikslas - ištirti senyvo amžiaus moterų fizinio aktyvumo, gyvenimo kokybės ir subjektyvios gerovès ypatumus bei tarpusavio sąsajas.

\section{Tyrimo medžiaga ir metodai}

Vienmomentis skerspjūvio tipo tyrimas pasitelkus patogiosios atrankos metodą atliktas $2017 \mathrm{~m}$. rugsẻjo-gruodžio mènesiais. Visoms tiriamosioms buvo atliktas trumpasis protinès būklès tyrimas (angl. Mini-Mental State Examination, $M M S E$ ) [16]. Taikyti šie įtraukimo ị tyrimą kriterijai: 60 metų ir vyresnis amžius; moteriška lytis; nuolatine gyvenamoji vieta - Lietuva; savanoriškas sutikimas dalyvauti tyrime. Neįtraukimo ị tyrimą kriterijai: vidutinis pažinimo funkcijos sutrikimas (MMSE $\leq 15$ balų), bet kurios lokalizacijos vèžiniai susirgimai, ūmūs susirgimai arba paūmejjusios lètinès ligos, sunki psichologinè trauma, patirta per pastaruosius 12 mèn. Tyrimui atlikti gautas Vilniaus regioninio bioetikos komiteto leidimas.

Tiriamųų apklausa buvo vykdoma tiesiogiai, naudojant bendraji ir specialiuosius klausimynus. Bendrajame klausimyne buvo registruojami sociodemografiniai duomenys (amžius, gyvenamoji vieta, šeiminė padètis, išsilavinimas, gyvenimo sąlygos, pajamų šaltiniai), išmatuoti ūgis ir kūno masè, apskaičiuotas kūno masès indeksas (KMI). Specialieji klausimynai buvo skirti ịvertinti senyvo amžiaus moterų fizinị aktyvumą, gyvenimo kokybę ir subjektyvią gerovę. 
Siekiant ịvertinti tiriamujų fizinio aktyvumo lygi buvo naudojamas fizinio aktyvumo klausimynas (angl. Physical Activity Scale for Elderly, PASE) [17], atspindintis fizini aktyvumą pastarujų 7 dienų laikotarpiu. Klausimynas sudarytas iš 10 klausimų, vertinančių tris pagrindines fizinio aktyvumo sritis: laisvalaikio, namų ruošos ir su darbu susijusias veiklas. Kiekvienas atsakymas ị klausimą turi savo ịvertị, kuris, pasitelkus metodikoje pateiktą algoritmą, buvo konvertuojami ị balus, kuriuos susumavus apskaičiuotas bendras fizinio aktyvumo ịvertis. Didesnis balų skaičius rodo didesnị fizinị aktyvumą.

Gyvenimo kokybei vertinti buvo naudotas kontrolès, autonomijos, savęs realizavimo ir malonumo (angl. Control, Autonomy, Self-realization, Pleasure, CASP-19) klausimynas, skirtas senyvo amžiaus žmonèms [18]. CASP-19 klausimynas sudarytas iš 19-os teiginių, vertinančių asmens kontrolès, autonomijos, savęs realizavimo, malonumo sritis (domenus). Teiginių atsakymų variantai pateikti 4 balų skalèje, nuo 1 - „,dažnai“ iki 4 - „niekada“. Didesnis balu skaičius rodo geresnę gyvenimo kokybę.

Subjektyvi gerovè buvo vertinama dviem klausimynais. Subjektyvios gerovès emocinis komponentas buvo vertinamas teigiamo ir neigiamo emocingumo, PANAS (angl. Positive and Negative Affect Schedule) klausimynu [19]. Klausimynas sudarytas iš 20 būdvardžių; kiekvieną būdvardị tiriamieji vertino pagal savo būseną pasirinkdami vieną iš penkių balų skalès teiginių: nuo 1 - „visiškai ne arba labai mažai““ iki 5 - „labai daug“. Dešimt būdvardžių apibūdina teigiamas emocijas - PANAS-PA (angl. Positive affect) ir dešimt būdvardžių - neigiamas emocijas PANAS-NA (angl. Negative affect). Kuo didesnè teigiamą ar neigiamą emocingumą apibūdinančių balų suma, tuo daugiau atitinkamai teigiamų ar neigiamų emocijų patiria tiriamasis.

Subjektyvios gerovės kognityvinis komponentas buvo vertinamas naudojantis pasitenkinimo gyvenimu skale SWLS (angl. Satisfaction With Life Scale,), sudaryta iš penkių teiginių, atspindinčių pasitenkinimą skirtingomis gyvenimo sritimis [20]. Sutikimas su kiekvienu teiginiu nurodamas/ pažymimas pagal septynių balų Likerto (Likert) skalę, nuo 1 - „,visiškai sutinku“ iki 7 - ,visiškai nesutinku”. Didesné balų suma nurodo didesnị pasitenkinimo gyvenimu lygị: 3135 balai - „labai patenkintas“, 26-30 balų - ,patenkintas“, 21-25 balai - „šiek tiek patenkintas“, 20 balų - „,neutralus“", 15-19 balų-, ,siek tiek nepatenkintas“, 10-14 balų - „,nepatenkintas“, 5-9 balai - „labai nepatenkintas“.

Statistinè duomenų analizè. Statistinè duomenų analizė atlikta naudojant „SPSS 18.0 for Windows“ programų paketą. Buvo skaičiuoti kintamujų vidurkiai ir standartinis nuokrypis pasirinkus 95 proc. pasikliautinį intervalą. Intervalinių kintamujų pasiskirstymo normališkumui ịvertinti taikytas Šapiro Vilko (Shapiro-Wilk) testas. Ryšiams tarp intervalinių kintamujų nustatyti apskaičiuotas Spirmano (Spearmen) koreliacijos koeficientas (r). Hipotezei apie vidurkių lygybę tikrinti, esant daugiau negu dviem nepriklausomoms imtims, taikyta dispersinè analizė (ANOVA). Skirtumai laikyti statistiškai reikšmingais, jeigu paklaidos tikimybės p reikšmé buvo lygi arba mažesnè už 0,05 .

\section{Rezultatai}

Dalyvauti tyrime buvo pakviestos 130 moterų. Iš jų 13 moterų atsisakè dalyvauti tyrime, o 14 neatitiko ịtraukimo i tyrimą kriterijų. Visus klausimynus užpilde 103 moterys, kurių duomenys ir buvo toliau analizuojami. Tirtų moteru vidutinis amžius buvo71,37 7,58 metai, jauniausioji buvo 60 metų amžiaus, vyriausioji - 94 metų. Tiriamujų pagrindiniai sociodemografiniai duomenys pateikti 1 lenteleje.

Didžiają tiriamujų dalị sudare miesto gyventojos, turinčios aukštaji išsilavinimą, apie pusę jų nurodè gyvenančios vienos. Vidutinès tirtų moterų gaunamos pajamos buvo $341,23 \pm 145,69$ eurų per ménesị. Didžioji dauguma tiriamuju (94,2 proc.) gavo senatvès pensiją, iš jų šešios dar gavo ir susijusių su darbo santykiais pajamų. Beveik penktadalis (17,5 proc.) visų tiriamujų nurodè, kad gavo papildomą finansinę artimujų paramą.

Nustatyta, kad tirtų moterų vidutinis ūgis buvo $161,06 \pm 4,82 \mathrm{~cm}$, vidutinè kūno masè $-71,04 \pm 10,40 \mathrm{~kg}$; apskaičiuotas KMI $-27,41 \pm 3,98 \mathrm{~kg} / \mathrm{m}^{2}$. Antropometrinių rodiklių analizė parodè, kad beveik pusė $(48,1$ proc.) tirtų

1 lentelè. Tiriamujų sociodemografiniai duomenys.

\begin{tabular}{|c|c|}
\hline Rodiklis & $\begin{array}{l}\text { Tiriamuju } \\
\text { skaičius, } \\
\text { n (proc.) }\end{array}$ \\
\hline \multicolumn{2}{|l|}{ Amžius, metais } \\
\hline $60-69$ & $52(50,5)$ \\
\hline $70-79$ & $38(36,9)$ \\
\hline $80+$ & $13(12,6)$ \\
\hline \multicolumn{2}{|l|}{ Gyvenamoji vieta } \\
\hline Miestas & $85(82,5)$ \\
\hline Kaimas & $18(17,5)$ \\
\hline \multicolumn{2}{|l|}{ Šeiminè padètis } \\
\hline Ištekèjusi & $30(29,1)$ \\
\hline $\begin{array}{l}\text { Neištekèjusi arba } \\
\text { išsiskyrusi }\end{array}$ & $29(28,2)$ \\
\hline Našlè & $44(42,7)$ \\
\hline \multicolumn{2}{|l|}{ Gyvena viena } \\
\hline Taip & $52(50,5)$ \\
\hline $\mathrm{Ne}$ & $51(49,5)$ \\
\hline \multicolumn{2}{|l|}{ Išsilavinimas } \\
\hline $\begin{array}{l}\text { Vidurinis, specialusis vidu- } \\
\text { rinis arba aukštesnysis }\end{array}$ & $38(36,9)$ \\
\hline Aukštasis & $65(63,1)$ \\
\hline
\end{tabular}


moterų turèjo antsvorị ir tik daugiau nei ketvirtadalio $(28,6$ proc.) kūno masė buvo normali.

Siekiant ịvertinti fizinio aktyvumo, gyvenimo kokybès ir subjektyvios gerovės amžinius ypatumus, tiriamosios buvo suskirstytos i 3 amžiaus grupes: 60-69 m., 70-79 m., 80 ir daugiau metų. Taip pat duomenys buvo analizuojami ir pagal tiriamųjų gyvenamają vietą. Senyvo amžiaus moterų fizinio aktyvumo, gyvenimo kokybès ir subjektyvios gerovès klausimynų įverčių pasiskirstymas pagal amžių ir gyvenamajją vietą pateikiamas 2 lentelëje.

PASE - senyvo amžiaus asmenų fizinio aktyvumo skalès klausimynas; CASP-19 - kontrolès, autonomijos, savęs realizavimo, malonumo bendras klausimynas; PANAS-PA
- teigiamo emocingumo klausimyno dalis; PANAS-NA neigiamo emocingumo klausimyno dalis; SWLS - pasitenkinimo gyvenimu skalė; SN - standartinis nuokrypis; *naudotas Mann-Whitney U testas

Gauti rezultatai parode, kad visose tirtose amžiaus grupèse PASE, CASP-19 (kontrolès, autonomijos sritys), PANAS-PA ir PANAS-NA klausimynų vidutiniai ịverčiai statistiškai reikšmingai skyrèsi. CASP-19 (savęs realizavimo, malonumo sritys) ir SWLS vidutiniai ịverčiai tirtose amžiaus grupèse statistiškai reikšmingai nesiskyrè. Analizuojant duomenis pagal gyvenamąją vietą nustatyti statistiškai reikšmingi skirtumai tarp visų tirtų rodiklių, išskyrus CASP-19 savęs realizavimo sriti.

2 lentelė. Fizinio aktyvumo, gyvenimo kokybės ir subjektyvios gerovės klausimynų įverčių pasiskirstymas pagal amžių ir gyvenamają vietą (vidurkis $\pm \mathrm{SN}$ ).

\begin{tabular}{|c|c|c|c|c|c|c|c|c|}
\hline \multirow[b]{2}{*}{ Klausimynai } & \multirow{2}{*}{$\begin{array}{l}\text { Bendri ịver- } \\
\text { čiai, balais }\end{array}$} & \multicolumn{3}{|c|}{ Amžius grupès } & \multirow[b]{2}{*}{$\begin{array}{c}\mathrm{p} \\
\text { (ANOVA) }\end{array}$} & \multicolumn{2}{|c|}{ Gyvenamoji vieta } & \multirow[b]{2}{*}{$\mathrm{p}^{*}$} \\
\hline & & $\begin{array}{c}60-69 \text { metai } \\
(\mathrm{n}=52)\end{array}$ & $\begin{array}{l}70-79 \text { metai } \\
(\mathrm{n}=38)\end{array}$ & $\begin{array}{c}80+\text { metai } \\
(\mathrm{n}=13)\end{array}$ & & $\begin{array}{l}\text { Miestas } \\
(\mathrm{n}=85)\end{array}$ & $\begin{array}{c}\text { Kaimas } \\
(\mathrm{n}=18)\end{array}$ & \\
\hline PASE & $103,23 \pm 66,59$ & $120,16 \pm 70,96$ & $109,60 \pm 46,43$ & $16,90 \pm 14,35$ & $<0,001$ & $\begin{array}{c}117,78 \pm \\
60,01\end{array}$ & $34,54 \pm 52,58$ & $<0,001$ \\
\hline CASP-19: & $36,79 \pm 10,07$ & $38,81 \pm 9,05$ & $37,26 \pm 10,14$ & $27,38 \pm 9,13$ & 0,001 & $38,41 \pm 9,46$ & $29,17 \pm 9,61$ & 0,001 \\
\hline Kontrolè & $7,15 \pm 2,79$ & $7,96 \pm 2,37$ & $7,18 \pm 2,45$ & $3,77 \pm 2,92$ & $<0,001$ & $7,67 \pm 2,51$ & $4,67 \pm 2,77$ & $<0,001$ \\
\hline Autonomija & $9,84 \pm 2,95$ & $10,23 \pm 2,55$ & $10,05 \pm 3,50$ & $7,69 \pm 1,65$ & $<0,02$ & $10,24 \pm 2,91$ & $8,00 \pm 2,45$ & 0,003 \\
\hline Savęs realizacija & $10,79 \pm 3,29$ & $11,19 \pm 3,19$ & $10,82 \pm 3,51$ & $9,08 \pm 2,56$ & 0,16 & $11,04 \pm 3,31$ & $9,61 \pm 2,95$ & 0,07 \\
\hline Malonumas & $9,02 \pm 3,61$ & $9,42 \pm 3,17$ & $9,21 \pm 3,87$ & $6,85 \pm 3,98$ & 0,06 & $9,47 \pm 3,45$ & $6,89 \pm 3,66$ & 0,01 \\
\hline PANAS-PA & $32,23 \pm 7,93$ & $34,23 \pm 6,56$ & $32,95 \pm 7,93$ & $22,15 \pm 5,46$ & $<0,001$ & $33,94 \pm 7,14$ & $24,17 \pm 6,53$ & $<0,001$ \\
\hline PANAS-NA & $21,30 \pm 7,46$ & $20,10 \pm 7,09$ & $21,18 \pm 7,26$ & $26,46 \pm 7,89$ & 0,02 & $20,45 \pm 7,27$ & $25,33 \pm 7,23$ & 0,02 \\
\hline SWLS & $23,98 \pm 5,37$ & $24 \pm 5$ & $24 \pm 6$ & $21 \pm 6$ & 0,2 & $25 \pm 5$ & $21 \pm 5$ & 0,01 \\
\hline
\end{tabular}

PASE - senyvo amžiaus asmenu fizinio aktyvumo skalès klausimynas; CASP-19-kontrolès, autonomijos, savęs realizavimo, malonumo bendras klausimynas; PANAS-PA - teigiamo emocingumo klausimyno dalis; PANAS-NA - neigiamo emocingumo klausimyno dalis; SWLS - pasitenkinimo gyvenimu skale; SN - standartinis nuokrypis; *naudotas Mann-Whitney U testas

3 lentelė. Fizinio aktyvumo, gyvenimo kokybės ir subjektyvios gerovės klausimynų ịverčių pasiskirstymas pagal šeiminę padetị ir išsilavinimą (vidurkis $\pm \mathrm{SN}$ ).

\begin{tabular}{|c|c|c|c|c|c|c|c|}
\hline \multirow[b]{2}{*}{ Klausimynai } & \multicolumn{3}{|c|}{ Šeiminè padėtis } & \multirow[b]{2}{*}{$\begin{array}{c}\mathrm{p} \\
\text { (ANOVA) }\end{array}$} & \multicolumn{2}{|c|}{ Aukštasis išsilavinimas } & \multirow[b]{2}{*}{$\mathrm{p}^{*}$} \\
\hline & $\begin{array}{l}\text { Susituokusi } \\
\quad(\mathrm{n}=30)\end{array}$ & $\begin{array}{c}\text { Išsiskyrusi } \\
\text { arba neište- } \\
\text { kejjusi } \\
(\mathrm{n}=29)\end{array}$ & $\begin{array}{l}\text { Našlè } \\
(\mathrm{n}=44)\end{array}$ & & $\begin{array}{l}\text { Taip } \\
(\mathrm{n}=65)\end{array}$ & $\begin{array}{c}\mathrm{Ne} \\
(\mathrm{n}=38)\end{array}$ & \\
\hline PASE & $115,93 \pm 49,74$ & $118,40 \pm 74,91$ & $84,58 \pm 67,63$ & 0,06 & $119,58 \pm 67,86$ & $75,27 \pm 54,67$ & 0,001 \\
\hline CASP-19: & $37,97 \pm 9,38$ & $39,62 \pm 8,96$ & $34,14 \pm 10,75$ & 0,06 & $38,15 \pm 9,45$ & $34,47 \pm 10,79$ & 0,11 \\
\hline Kontrolè & $7,30 \pm 2,44$ & $8,31 \pm 2,22$ & $6,27 \pm 3,08$ & 0,01 & $7,48 \pm 2,54$ & $6,58 \pm 3,12$ & 0,18 \\
\hline Autonomija & $9,80 \pm 2,78$ & $10,83 \pm 3,20$ & $9,23 \pm 2,78$ & 0,08 & $10,42 \pm 2,72$ & $8,87 \pm 3,10$ & 0,01 \\
\hline $\begin{array}{l}\text { Savęs realiza- } \\
\text { cija }\end{array}$ & $11,27 \pm 3,18$ & $10,83 \pm 3,30$ & $10,43 \pm 3,38$ & 0,57 & $10,80 \pm 3,37$ & $10,76 \pm 3,18$ & 0,85 \\
\hline Malonumas & $9,60 \pm 3,41$ & $9,66 \pm 3,04$ & $8,20 \pm 3,98$ & 0,14 & $9,46 \pm 3,43$ & $8,26 \pm 3,83$ & 0,16 \\
\hline PANAS-PA & $33,53 \pm 6,82$ & $33,14 \pm 7,48$ & $30,75 \pm 8,81$ & 0,26 & $33,68 \pm 7,45$ & $29,76 \pm 8,23$ & 0,02 \\
\hline PANAS-NA & $21,17 \pm 7,91$ & $19,93 \pm 7,15$ & $22,30 \pm 7,38$ & 0,42 & $19,37 \pm 6,22$ & $24,61 \pm 8,30$ & 0,002 \\
\hline SWLS & $25 \pm 6$ & $24 \pm 4$ & $23 \pm 6$ & 0,43 & $24 \pm 5$ & $23 \pm 6$ & 0,38 \\
\hline
\end{tabular}

PASE - senyvo amžiaus asmenu fizinio aktyvumo skalès klausimynas; CASP-19-kontrolès, autonomijos, savęs realizavimo, malonumo bendras klausimynas; PANAS-PA - teigiamo emocingumo klausimyno dalis; PANAS-NA - neigiamo emocingumo klausimyno dalis; SWLS pasitenkinimo gyvenimu skale; $S N$ - standartinis nuokrypis; *naudotas Mann-Whitney U testas 
4 lentelė. Fizinio aktyvumo, gyvenimo kokybės ir subjektyvios gerovės klausimynų ịverčių tarpusavio sąsajos (r).

\begin{tabular}{|l|c|c|c|c|c|c|c|c|c|}
\hline Klausimynai & PASE & CASP-19 & Kontrolè & $\begin{array}{c}\text { Auto- } \\
\text { nomija }\end{array}$ & $\begin{array}{c}\text { Savęs rea- } \\
\text { lizavimas }\end{array}$ & $\begin{array}{c}\text { Malo- } \\
\text { numas }\end{array}$ & PANAS-PA & PANAS-NA & SWLS \\
\hline PASE & - & & & & & & & & \\
\hline CASP-19: & $0,38^{*}$ & - & & & & & & & \\
\hline Kontrole & $0,37^{*}$ & $0,72^{*}$ & - & & & & & & \\
\hline Autonomija & $0,29^{*}$ & $0,74^{*}$ & $0,58^{*}$ & - & & & & & \\
\hline Savęs realizavimas & $0,28^{*}$ & $0,82^{*}$ & $0,42^{*}$ & $0,38^{*}$ & - & & & & \\
\hline Malonumas & $0,32^{*}$ & $0,87^{*}$ & $0,47^{*}$ & $0,48^{*}$ & $0,75^{*}$ & - & & & \\
\hline PANAS-PA & $0,41^{*}$ & $0,55^{*}$ & $0,5^{*}$ & $0,4^{*}$ & $0,47^{*}$ & $0,45^{*}$ & - & & \\
\hline PANAS-NA & $-0,24^{* *}$ & $-0,51^{*}$ & $-0,3^{*}$ & $-0,46^{*}$ & $-0,44^{*}$ & $-0,48^{*}$ & $-0,33^{*}$ & - & - \\
\hline SWLS & $0,23^{* *}$ & $0,6^{*}$ & $0,43^{*}$ & $0,38^{*}$ & $0,62^{*}$ & $0,56^{*}$ & $0,6^{*}$ & $-0,5^{*}$ & - \\
\hline
\end{tabular}

PASE - senyvo amžiaus asmenu fizinio aktyvumo skalès klausimynas; CASP-19 - kontrolès, autonomijos, savęs realizavimo, malonumo bendras klausimynas; PANAS-PA - teigiamo emocingumo klausimyno dalis; PANAS-NA - neigiamo emocingumo klausimyno dalis; SWLS - pasitenkinimo gyvenimu skale; ${ }^{*} p<0,01 ;{ }^{*} p<0,05$

Tolimesnès analizès metu buvo siekta ịvertinti fizinio aktyvumo, gyvenimo kokybės ir subjektyvios gerovès klausimynų vidutinių ịverčių pasiskirstymą, atsižvelgiant ị tirtu moterų šeiminę padèti ir aukštaji išsilavinimą. Gauti rezultatai pateikti 3 lentelèje.

Atlikta analizè parodè, kad tik CASP-19 klausimyno kontrolès srityje vidutiniai įverčiai statistiškai reikšmingai skyrèsi atsižvelgiant į šeiminę padètį: vidutiniai įverčiai buvo mažiausi našlių moteru grupejje, aukščiausi - neištekejjusių arba išsiskyrusių moteru grupeje. Vertinant gautus rodiklius aukštajį išsilavinimą turinčių moterų grupeje nustatyta, kad PASE, CASP-19 klausimyno autonomijos srities vidutiniai ìverčiai buvo statistiškai reikšmingai didesni, negu neturinčiu aukštojo išsilavinimo moterų grupejje. Taip pat aukštajj̣ išsilavinimą turinčios moterys patiria daugiau teigiamu (PANAS-PA) ir mažiau neigiamų (PANAS-NA) emocijų. CASP-19 (kontrolès, savęs realizavimo, malonumo sritys) ir SWLS vidutiniai ịverčiai statistiškai reikšminga nesiskyrė tarp aukštaji išsilavinimą turinčiu ir neturinčiu moterų.

Moterų PASE, CASP-19, PANAS-PA, PANAS-NA ir SWLS klausimynų vidutinių įverčių pasiskirstymas buvo analizuojamas atsižvelgiant $i$ tai, ar jos gyvena vienos, ar su kitais asmenimis. Gauti rezultatai parode, kad po vieną gyvenančių moterų CASP-19 bendras įvertis $(\mathrm{p}<0,001)$ ir CASP19 klausimyno kontrolès $(p=0,03)$, autonomijos $(p<0,001)$, malonumo $(p=0,04)$ srityse vidutinès ịverčių reikšmès yra statistiškai reikšmingai didesnès, negu tų moterų, kurios gyvena ne vienos.

Siekiant ịvertinti fizinio aktyvumo, gyvenimo kokybès ir subjektyvios gerovès klausimynų vidutinių įverčių tarpusavio sąsajas buvo atlikta koreliacinè analizè pasitelkus Spirmano (Spearmen) koreliacijos koeficientą, gauti rezultatai pateikti 4 lenteleje.

Nustatyta, kad visi tirti fizinio aktyvumo, gyvenimo kokybės ir subjektyvios gerovès klausimynų ịverčiai yra tarpusavyje statistiškai reikšmingai susiję. Silpni teigiami koreliaciniai ryšiai buvo nustatyti tarp PASE ir CASP-19, CASP-19 kontrolès, autonomijos, savęs realizavimo, malonumo, SWLS ịverčių. Silpnas neigiamas koreliacinis ryšis rastas tarp PASE ir PANAS-NA ịverčių, PASE vidutiniškai stipriai koreliavo su PANAS-NA vidutiniais ịverčiais. Analizuojant gyvenimo kokybès sąsajas su subjektyvia gerove, nustatyti vidutinio stiprumo koreliaciniai ryšiai tarp CASP19, PANAS-PA, PANAS-NA ir SWLS. CASP-19 klausimyno kontrolès, autonomijos, savęs realizavimo, malonumų sričių ịverčiai taip pat koreliavo su subjektyvią gerovę vertinančių klausimynų įverčiais.

\section{Rezultatų aptarimas}

Mūsų tyrimo rezultatai atskleidè, kad $80 \mathrm{~m}$. vyresnio amžiaus moterų fizinis aktyvumas yra mažesnis, gyvenimo kokybè blogesnè, jos patiria mažiau teigiamų ir daugiau neigiamų emocijų, negu jaunesnès (60-79 m.) senyvo amžiaus moterys. Mieste gyvenančių, aukštajị išsilavinimą turinčių moterų fizinis aktyvumas didesnis, jos patiria daugiau teigiamų ir mažiau neigiamų emocijų, negu gyvenančios kaime.

Mieste gyvenančių moterų gyvenimo kokybè irgi buvo geresnè, tačiau mieste ir kaime gyvenančių moterų gyvenimo kokybė nesiskyrė atsižvelgiant ị šeiminę padètị ir išsilavinimą. Išanalizavę tirtų moterų fizinị aktyvumą, nustatėme, kad PASE vidutiné reikšmė yra 103,23 $\pm 66,59$ balai. Fizinis aktyvumas buvo tirtas ir kitose šalyse pasitelkus PASE klausimyną. Kanadoje $60 \mathrm{~m}$. ir vyresnio amžiaus asmenų grupejje PASE vidutinè reikšmè buvo $139 \pm 58$ balai [21], Japonijoje - 118,2 \pm 40,4 [22], Kanados provincijoje esančio Saskatūno mieste $50 \mathrm{~m}$. ir vyresnio amžiaus moterų fizinis aktyvumas pagal PASE buvo 102,9 $\pm 61,4$ balai [23]. Toje pačioje šalyje atliktų tyrimų rezultatai prieštaringi: Kanados Saskatūno mieste buvo tirti jaunesni asmenys, tačiau gauti PASE vidutiniai ịverčiai yra ženkliai mažesni negu kitoje 
Kanados srityje atlikto tyrimo rezultatai $[21,22]$. K. E. Chad su bendraautoriais irgi suskirste tiriamąsias 3 amžiaus grupes: 50-64 m., 65-69 m., 80 m. ir daugiau [23]. Nustatyta, kad $80 \mathrm{~m}$. ir vyresnio amžiaus moterų fizinis aktyvumas yra statistiškai reikšmingai mažesnis negu jaunesnių (50-79 m.), kaip ir mūsų tyrime. Gyvenimo kokybė ir gyvenimo kokybės kontrolés, autonomijos srities ịverčiai irgi buvo mažiausi 80 m. amžiaus moterų grupeje.

Mūsų tyrimo rezultatai parodè, kad bendras CASP-19 ivvertis buvo $36,8 \pm 10,1$. Gautas rezultatas yra panašus ị tą, kuri gavo $\mathrm{H}$. Pikhart su bendraautoriais tirdamas gyvenimo kokybę Rytų Europos valstybėse: Rusijos populiacijoje $33,1 \pm 8,5$ ir Čekijos populiacijoje $-34,3 \pm 10.2$, Lenkijos populiacijoje - 36,8 $\pm 8,9$ [24]. Analizuojant mūsų tirtų moterų subjektyvios gerovès emocini komponentą buvo nustatyta, kad $80 \mathrm{~m}$. amžiaus moterys patiria mažiau teigiamų ir daugiau neigiamų emocijų, palyginus su jaunesnėmis senyvo amžiaus moterimis. Nenustatyta statistiškai reikšmingų skirtumų tarp tirtų amžiaus grupių lyginant subjektyvios gerovės kognityvinio komponento - pasitenkinimo gyvenimu - vidutinius įverčius. C. McConville su bendraautoriais atlikto tyrimo rezultatai parodè, kad senyvo amžiaus moterų, gyvenančių Šiaurès Airijoje, PANAS-PA iverčiai buvo $27,73 \pm 5,38$, Romoje - 19,07 $\pm 6,66$, Grenoblyje $-26,19 \pm 5,97$, Klermono-Ferane $-25,12 \pm 4,68$ balai. Mūsų tyrimo metu gautas PANAS-PA vidutinis ịvertis buvo $33,53 \pm 6,82$, PANAS-NA - 21,17 $\pm 7,91$ balams. Nustatytas senyvo amžiaus moterų neigiamas emcoingumas Šiaurès

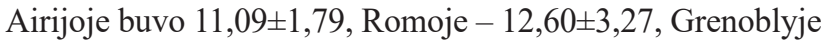
$-13,76 \pm 4,18$, Klermono-Ferane - 12,39 2,81 [25].

Ivertinus tiriamų moterų fizinio aktyvumo, gyvenimo kokybės ir subjektyvios gerovės ypatumus atsižlegiant ị gyvenamają vietą, nustatyta, kad mūsų tirtų moterų, gyvenančių mieste, tirti rodikliai yra aukštesni, negu moterų, gyvenančių kaime. Fizinio aktyvumo įverčio rezultatai sutampa su A. Juozulyno ir bendraautoriu atlikto tyrimo viena iš išvadų, teigiančių, kad kaime gyvenantys asmenys nevertina fizinio aktyvumo kaip prevencinès priemonės, galinčios pagerinti sveikatą [4]. Analizuojant mūsų gautus duomenis pagal šeiminę padètí, nustatyta, kad gyvenimo kokybès kontrolès srities balai buvo didesni neištekejjusių arba išsiskyrusių moterų grupejje, negu tu, kurios gyvena susituokusios arba yra našlès. Aukštaji išsilavinimą turinčių moterų fizinis aktyvumas buvo didesnis, jos patiria daugiau teigiamų emocijų ir mažiau neigiamų negu tos, kurių išsilavinimas buvo mažesnis. Šie rezultatai priešingi negu tie, kuriuos gavo R. Valintèlienè su bendrautoriais [5].

Vienas iš mūsų tyrimo trūkumų: i tyrimą neįtraukti senyvo amžiaus vyrai. Taip pat nebuvo atsižvelgta ị tyrimo dalyvių vaistų vartojimą, kas galèjo turèti ịtakos tyrimo rezultatams.

\section{Išvados}

1. Mūsų tyrimo rezultatai parodè, $\mathrm{kad} 80 \mathrm{~m}$. ir vyresnio amžiaus moterų fizinis aktyvumas mažesnis, gyvenimo kokybè blogesnè, jos patyrè mažiau teigiamų ir daugiau neigiamų emocijų, negu jaunesnès (60-79 m.) senyvo amžiaus moterys. Mieste gyvenančių, aukštaji išsilavinimą turinčių moterų fizinis aktyvumas buvo didesnis, jos patyre daugiau teigiamų ir mažiau neigiamų emocijų negu gyvenančios kaime. Mieste gyvenančių moterų gyvenimo kokybẻ buvo geresnè nei gyvenančių kaime.

2. Senyvo amžiaus moterų fizinis aktyvumas stipriai susijęs su teigiamu emocingumu, gyvenimo kokybè - su teigiamu emocingumu ir pasitenkinimu gyvenimu. Pasitenkinimas gyvenimu buvo susijęs su savęs realizavimo sritimi.

\section{Literatūra}

1. Lietuvos statistikos departamento rodiklių duomenų bazė [žiūrèta 2018 m. birželio 14 d.]. Prieiga per internetą: https://osp.stat. gov.lt/statistiniu-rodikliu-analize\#/.

2. The 2018 Ageing Report: Underlying Assumptions and Projection Methodologies [žiūrèta $2018 \mathrm{~m}$. birželio 14 d.]. Prieiga per internetą: https://ec.europa.eu/info/sites/info/files/economy-finance/ip065_en.pdf.

3. Constitution of the World Health Organization. In: World Health Organization: Basic documents. 45th ed. Geneva: World Health Organization; 2006.

4. Juozulynas A, Saviciute R, Butikis M. et al. Healthy Lifestyle peculiarity of older people. Sveikatos mokslai, 2010;5:3519-3523.

5. Valintèlienė R., Varvuolienė R., Kranauskas A. Lietuvos gyventojų fizinis aktyvumas, vertinant GPAQ metodu. Visuomenés sveikata, 2012;4(59):67-75.

6. Lollgen H, Bockenhoff A, Knapp G. Physical activity and all-cause mortality: an updated meta-analysis with different intensity categories. Int J Sports Med 2009;30(3):213-24.

https://doi.org/10.1055/s-0028-1128150

7. Vagetti GC, Barbosa Filho VC, Moreira NB. et al. Association between physical activity and quality of life in the elderly: a systematic review, 2000-2012. Rev Bras Psychiatr 2014;36(1):76-88.

https://doi.org/10.1590/1516-4446-2012-0895

8. Haas BK. A multidisciplinary concept analysis of quality of life. West J Nurs Res 1999;21(6):728-42.

https://doi.org/10.1177/01939459922044153

9. Diener E. Subjective well-being. Psychol Bull 1984;95(3):54275.

https://doi.org/10.1037/0033-2909.95.3.542

10. Šilinskas G., Žukauskienė R. Subjektyvios gerovės išgyvenimas ir su juo susiję veiksniai vyrų imtyje. Psichologija, 2004;30:47-58.

11. Zukauskiene R, Navaitiene J, Kanapinskaite J. Social demographic and personality factors related to woman's subjective 
well-being. Socialinis darbas, 2005;4(1):4-13.

12. Daukantaite D, Zukauskienè R. Swedish and Lithuanian employed womens's subjective well-being. Int J Soc Welf 2006;15(1):23-30.

https://doi.org/10.1111/j.1468-2397.2006.00441.x

13. Vaznonienė G. Subjektyvios pagyvenusių žmonių gyvenimo kokybės socialiniai ekonominiai veiksniai. Sociologija, 2010; 2(27):186-204.

14. Miežytė-Tijūšienė J., Bulotaitė L. Pensinio amžiaus žmonių socialinis aktyvumas bei psichologinè savijauta. Gerontologija, 2012;13(4):199-205

15. Pawlowski T, Downward P, Rasciute S. Subjective well-being in European countries on the age-specific impact of physical activity. Eur Rev Aging Phys Act 2011;8(2):93-102.

https://doi.org/10.1007/s11556-011-0085-x

16. Folstein MF, Folstein SE, McHugh PR. "Mini-mental status". A practical method for grading the cognitive state of patients for the clinician". Journal of Psychiatric Research1975;12(3):189-98.

https://doi.org/10.1016/0022-3956(75)90026-6

17. Washburn RA, Smith KW, Jette AM, Janney CA. The Physical Activity Scale for the Elderly (PASE): development and evaluation. J Clin Epidemiol 1993;46(2):153-62.

https://doi.org/10.1016/0895-4356(93)90053-4

18. Hyde M, Wiggins RD, Higgs P, Blane DB. A measure of quality of life in early old age: the theory, development and properties of a needs satisfaction model (CASP-19). Aging Ment Health 2003;7(3):186-94.

https://doi.org/10.1080/1360786031000101157

19. Watson D, Clark LA, Tellegen A. Development and validation of brief measures of positive and negative affect: the PANAS scales. J Pers Soc Psychol 1988;54(6):1063-70.

https://doi.org/10.1037/0022-3514.54.6.1063

20. Diener E, Emmons RA, Larsen RJ, Griffin S. The Satisfaction With Life Scale. J Pers Assess 1985;49(1):71-5. https://doi.org/10.1207/s15327752jpa4901_13

21. Logan SL, Gottlieb BH, Maitland SB, Meegan D, Spriet LL. The Physical Activity Scale for the Elderly (PASE) questionnaire; does it predict physical health? Int J Environ Res Public Health 2013;10(9):3967-86.

https://doi.org/10.3390/ijerph10093967

22. Hagiwara A, Ito N, Sawai K, Kazuma K. Validity and reliability of the Physical Activity Scale for the Elderly (PASE) in Japanese elderly people. Geriatr Gerontol Int 2008;8(3):143-51. https://doi.org/10.1111/j.1447-0594.2008.00463.x

23. Chad KE, Reeder BA, Harrison EL, Ashworth NL, Sheppard SM, Schultz SL. et al. Profile of physical activity levels in community-dwelling older adults. Med Sci Sports Exerc 2005;37(10):1774-84.

https://doi.org/10.1249/01.mss.0000181303.51937.9c
24. Pikhart H, Nicholson A, Pajak A, Malyutina S, Kubinova R, Peasey A. et al. Life-course social status and quality of life in early old age in Eastern Europe: the HAPIEE study. Eur J of Public Health 2007; 17, 120 - 120

25. McConville C, Simpson EE, Rae G, Polito A, Andriollo-Sanchez M, Meunier N. et al. Positive and negative mood in the elderly: the ZENITH study. Eur J Clin Nutr 2005;59 Suppl 2:S22-5.

https://doi.org/10.1038/sj.ejen.1602293

\section{PHYSICAL ACTIVITY, QUALITY OF LIFE AND SUBJECTIVE WELL-BEING PECULIARITIES AND ASSOCIATIONS IN ELDERLY WOMEN \\ A.Černovas, V.Alekna, M.Tamulaitienė, G.Katavičiūtė, R.Stukas}

Key words: elderly, women, physical activity, quality of life, subjective well-being.

Summary

Introduction. The aim of our study to investigate physical activity, quality of life and subjective well-being peculiarities and associations in elderly women aged 60 years and older.

Methods. A Cross-sectional study was performed in 2018 September - December. Data were collected by face to face interviewing. Sociodemographic characteristics, height, body weight, body mass index was obtained. Physical activity was evaluated with Physical Activity Scale for Elderly (PASE). Quality of life was measured using Control, Autonomy, Pleasure, and Self-realization (CASP-19) questionnaire. Well-being was assessed using two questionnaires: 1) Positive Affect Negative Affect Scale (PANAS) questionnaire, using both positive (PA) and negative affect (NA) subscales 2) Satisfaction With Life Scale (SWLS). The statistical analysis was performed using SPSS software for Windows (version 18.0).

Results. The study involved 103 women aged $71.37 \pm 7.58$ years. The majority was higher educated and more than half of them lived alone. It was investigated PASE, CASP-19 (control, autonomy domains), PANAS-PA and PANAS-NA scores was different between $60-69 y, 70-79 y$ and $80 y$ and older age groups. The CASP-19 questionnaire result was the lowest in the group of widows, the highest in the group of non-existent or dismissed women. Moderate associations between PASE and PANAS-PA scores was established. It was found correlations between CASP-19, PANAS-PA, PANAS-NA and SWLS scores

Conclusions. 1) Our study showed that 80 years and older women have lower physical activity, poorer quality of life, experiencing less positive and more negative emotions than younger (60-79 years) elderly women. Urban area women, higher educated have a greater physical activity, more positive and less negative emotions. The quality of life of women living in urban areas was better than those living in rural areas. 2) Associations between physical activity and negative emotions was moderate strong as well as quality of life and subjective well-being.

Correspondence to: andrejus.cernovas@mf.vu.1t

Gauta 2018-07-20 